1. MBBS, MRCPS(Glasgow)

FCPS (General Surgery)

Clinical fellow, Liver Transplant and

General Surgery

Pir Abdul Qadir Shah Institute of Medical Sciences, Gambat.

2. MBBS, FCPS (General Surgery)

Senior Consultant Liver Transplant and General Surgery

Pir Abdul Qadir Shah Institute of Medical sciences, Gambat.

3. MBBS, FCPS (General Surgery)

Assistant Consultant Liver

Transplant and General Surgery Pir Abdul Qadir Shah Institute of Medical Sciences, Gambat.

4. MBBS

Resident General Surgery Unit A, Khyber Teaching Hospital, MTI, Peshawar.

Correspondence Address:

Dr. Kaleem Ullah

Department of Liver Transplant and

General Surgery

Pir Abdul Qadir Shah Institute of

Medical Sciences, Gambat.

drkaleempk@gmail.com

Article received on:

28/08/2020

Accepted for publication:

29/10/2020

\section{Comparison of outcome of interrupted versus continuous closure technique of rectus sheath in emergency laparotomies patients in terms of wound dehiscence.}

\author{
Kaleem Ullah', Shams Uddin², Azam Shoib ${ }^{3}$, Muhmmad Danish Yaseen ${ }^{4}$
}

ABSTRACT... Objective: To compare outcome of interrupted versus continuous closure of rectus sheath in emergency laparotomy patients, in terms of wound dehiscence. Study Design: Randomized Controlled Trail. Setting: Department of Surgery Pir Abdul Qadir Shah Institute of Medical Sciences, Gambat. Period: $1^{\text {st }}$ January to $30^{\text {th }}$ June 2020. Material \& Methods: Total duration of study was 6 months. Total of 150 patients (75 in each group) were studied. Interrupted closure of rectus sheath was done in group "A" patients while continuous closure was done in group "B" patients, and efficacy in terms of wound dehiscence was compared in both groups. Results: Overall male to female ratio was1.29:1. The average age of the patients was 39.41 years +13.02SD. Wound dehiscence in Group "A" was $2.6 \%$ while $10.7 \%$ in Group"B" patients with significant p-value of 0.049. Conclusion: Interrupted closure of Rectus sheath in emergency laparotomy is more effective than continuous closure in preventing wound dehiscence.

Key Words: $\quad$ Continuous Closure, Dehiscence and Laparotomy, Interrupted Closure.

Article Citation: Kaleem Ullah, Shams Uddin, Azam Shoib, Muhmmad Danish Yaseen. Comparison of outcome of interrupted versus continuous closure technique of rectus sheath in emergency laparotomies patients in terms of wound dehiscence. Professional Med J 2021; 28(4):455-458. https://doi.org/10.29309/TPMJ/2021.28.04.6020

\section{INTRODUCTION}

Fascial dehiscence is a common complication in post-emergency laparotomy patients, which appear early as burst abdomen or late as incisional hernia. Patients with this morbidity often need secondary fascial closure..$^{1,2}$

Emergency laparotomy is a common surgical procedure, and wound dehiscence in these patients remains a worrisome complication in postoperative period. Incidence of postlaparotomy wound dehiscence is quoted as $0.25 \%$ to $3 \% .^{3}$

The proper abdominal wall closure needs combination of an accurate surgical technique and an appropriate suture material with sufficient suture length and diameter, in order to prevent this complication. ${ }^{4}$ Technique of abdominal wall closure plays an important role in fascial dehiscence prevention. Also, during surgery, measures should be taken to reduce tissue hypoxia and surgical infections. Comorbidities like chronic pulmonary disease, ascites, jaundice, anemia and malnutrition also affect wound healing. ${ }^{5}$ Evaluation and possible correction of these factors is very essential in prevention of dehiscence. ${ }^{6}$

According to another study, excessive tension should be avoided during closure. ${ }^{7}$ Patients with generalized peritonitis and malignancy need special attention regarding wound closure. ${ }^{8}$

Many new techniques have been developed in a hope to prevent or reduce the risk of fascial dehiscence, but burst abdomen remains an unavoidable morbidity. ${ }^{9}$ Also, in recent large multicenter trials surgeons at various institutions showed lack of consensus regarding optimal technique for midline abdominal incision closure in emergency laparotomies. ${ }^{4}$

The aim of this study was to determine the superior 
technique for midline abdominal incisions closure in emergency laparotomy patients. This study will provide us local statistics and the results will be shared with the general surgeons.

\section{MATERIAL \& METHODS}

This randomized controlled study was conducted at Surgical department at of Pir Abdul Qadir Shah Institute of Medical Sciences, Gambat from $1^{\text {st }}$ January to $30^{\text {th }}$ June 2020 . Total Duration of study was 06 months. Total 150 Patients were studied. 75 in each group. All patients with age group between 18 to 60 years who underwent emergency laparotomy were included in this study. Malnourished patients with body mass index of $<15 \mathrm{Kg} / \mathrm{m}^{2}$, obese patient with BMI of $>30 \mathrm{Kg} / \mathrm{m}^{2}$; Diabetics, patients with underlying malignancy and immuno-compromised patients were excluded from this study.

Approval was taken from the hospital ethical committee PASQJIMS/IRB/710. The purpose and benefits of study were explained to all patients. Verbal and written informed consent was obtained from all patients. Demographic characteristics like name, age, sex, address of all patients were recorded. Complete history was taken and examination of all patients was done. Base line investigations like $\mathrm{FBC}$, serum creatinine, x-ray chest, ECG, RBS and viral profile were done. Appropriate resuscitation of all patients followed by emergency laparotomy was done. Patients in Group "A" were closed with Interrupted closure technique and Group "B" patients underwent continuous closure. All laparotomies were done by consultant surgeon. Same suture material i.e. Prolene No. 1 with a length of at least 4 times the length of the wound was used in both groups. All patients were followed Post operatively for 4 weeks for wound dehiscence.

All information's were recorded on a pre-designed proforma. All the analysis was done in SPSS 20.0.

\section{RESULTS}

Gender wise distribution showed male to female ratio of 1.41:1 in Group "A" while Group "B" patients was having male to female ratio of 1.14:1. Overall Male to female ratio was 1.29:1.
Average age of the patient in Group "A" was 38.64 years $\pm 13.14 S D$. While in Group "B" average age of the patient was 40.17 years \pm 12 .92SD. The overall average age of the patients was 39.41 years $\pm 13.02 S D$. Wound dehisence in Group"A" was $2.6 \%$ while $10.7 \%$ in Group B patients with significant P-value of $0.049 \%$ (Table-I)

\begin{tabular}{|l|c|c|}
\hline \multicolumn{1}{|c|}{ Variable } & Group A & Group B \\
\hline Number of Patients & 75 & 75 \\
\hline Gender & & \\
\hline Male & $44(58.6 \%)$ & $40(53.3 \%)$ \\
\hline Female & $31(41.4 \%)$ & $35(46.7 \%)$ \\
\hline Fascial Dehiscence & $2(2.6 \%)$ & $8(10.7 \%)$ \\
\hline & Table-l. & \\
\hline
\end{tabular}

\section{DISCUSSION}

Most commonly used incision during emergency laparotomies is midline incision, because it is easy to open in no time, usually blood sparing and gives access to all quadrants of the abdomen. ${ }^{10}$

Post-operatively wound dehiscence appears mostly between fifth and eighth day. ${ }^{11,12}$ Wound strength during this period depends on the suture technique and material. ${ }^{13}$ Technique of wound closure involves selection between interrupted and continuous closure, fascial bite size, stitch interval, size and length of suture material used. ${ }^{14}$ There are numerous studies with contradictory results about wound strength in continuous versus interrupted suture techniques. ${ }^{15}$

With Smead-Jones interrupted closure technique with polypropylene and monofilament steel, fascial dehiscence incidence is less than $1 \%$ in laparotomies closure. ${ }^{16}$ Polyglycolic acid sutures are also equally effective when used with the same technique. ${ }^{17}$ While closures with catgut suture with this same technique does not prevent wound dehiscence because it breaks easily. ${ }^{16}$

In our study, we recorded dehiscence of $10.7 \%$ in patients with continuous closure technique compared to $2.6 \%$ in patients with interrupted closure. While a study done in India quoted dehiscence rate of $4.55 \%$ in patients with interrupted closure technique, compared to 
wound dehiscence of $15.70 \%$ with continuous closure technique. ${ }^{18}$ In another study, done by Murtaza B had showed dehiscence rate of $10 \%$ with interrupted technique, compared to dehiscence of $20 \%$ in patients with continuous technique. $^{9}$

Himanshu Gupta et al published a Meta-analysis, the most up-to-date and comprehensive analysis, with 23 trials. It showed a significant low risk of fascial dehiscence incidence of $2.17 \%$ with interrupted closure technique in comparison of $14.8 \%$ incidence with continuous closure technique. ${ }^{19}$

\section{CONCLUSION}

Our study showed that Interrupted closure is more effective than continuous closure technique in dehiscence prevention post-laparotomy midline closure. However, increased cost and more time requirement during closure makes this technique less popular among General surgeons. Also long term complications like knots irritation and more chances of stitch sinus formation has limited the use of this technique. So, large scale studies are recommended to show the actual status of both the techniques.

\section{Copyright@ 29 Oct, 2020.}

\section{REFERENCES}

1. Gislason H, Grønbech JE, Søreide O. Burst abdomen and incisional hernia after major gastrointestinal operations-comparison of three closure techniques. The European journal of surgery= Acta chirurgica. 1995 May; $161(5): 349-54$.

2. Geçim IE, Koçak S, Ersoz S, Bumin C, Aribal D. Recurrence after incisional hernia repair: results and risk factors. Surgery today. 1996 Aug 1; 26(8):607-9.

3. Spiliotis J, Tsiveriotis $K$, Datsis AD, Vaxevanidou A, Zacharis G, Giafis K, Kekelos S, Rogdakis A. Wound dehiscence: Is still a problem in the 21th century: A retrospective study. World Journal of Emergency Surgery. 2009 Dec;4(1):12

4. Rahbari NN, Knebel P, Diener MK, Seidlmayer C, Ridwelski K, Stöltzing H, Seiler CM. Current practice of abdominal wall closure in elective surgery-ls there any consensus?. BMC surgery. 2009 Dec;9(1):8
5. Van Ramshorst GH, Nieuwenhuizen J, Hop WC, Arends P, Boom J, Jeekel J, Lange JF. Abdominal wound dehiscence in adults: development and validation of a risk model. World journal of surgery. 2010 Jan 1; 34(1):20.

6. Al-Faouri AF, Alzu'bi AA, Ajarma KY, Abbadi AM, Haddadin SW. Interrupted braided sutures versus running monofilament sutures in the prevention of abdominal wound dehiscence: A prospective nonrandomized case-control trial. JRMS. 2017 Mar; 24(1):31-7.

7. Israelsson LA, Millbourn D. Closing midline abdominal incisions. Langenbeck's archives of surgery. 2012 Dec $1 ; 397(8): 1201-7$

8. Murtaza B, Khan NA, Sharif MA, Malik IB, Mahmood A. Modified midline abdominal wound closure technique in complicated/high risk laparotomies. $\mathrm{J}$ Coll Phys Surg Pak. 2010 Jan 1; 20(1):37-41.

9. Dietz UA, Debus ES, Thiede A, Kuhfuss I. Inverting bilateral figure-of-eight suture of the rectus sheath after burst abdomen with destruction of the linea alba: A new technique. Journal of plastic, reconstructive $\&$ aesthetic surgery. 2007 Apr 1; 60(4):389-92.

10. Yahchouchy-Chouillard E, Aura T, Picone O, Etienne JC, Fingerhut A. Incisional hernias. Digestive Surgery. 2003; 20(1):3-9.

11. Kreszinger $M$, Delimar $D$, Kos J, Jovanov $N$, Vnuk D, Maticic D, Pirkic B, Stejskal M, Capak D. Wound strength after midline laparotomy: A comparison of four closure techniques in rats. Veterinarski arhiv. 2007 Oct 19; 77(5):397.

12. Carlson MA, Condon RE. Polyglyconate (Maxon (R)) versus nylon suture in midline abdominal incision closure: A prospective randomized trial. American Surgeon. 1995 Nov 1; 61(11):980-3.

13. Höer J, Anurov M, Titkova S, Klinge U, Töns C, Öttinger $A$, Schumpelick V. Influence of suture material and suture technique on collagen fibril diameters in midline laparotomies. European surgical research. 2000; 32(6):359-67.

14. Jenkins TP. The burst abdominal wound: A mechanical approach. British Journal of Surgery. 1976 Nov; 63(11):873-6.

15. Riou JP, Cohen JR, Johnson Jr H. Factors influencing wound dehiscence. The American journal of surgery. 1992 Mar 1; 163(3):324-30. 
16. Pollock AV, Greenall MJ, Evans M. Single-layer mass closure of major laparotomies by continuous suturing. Journal of the Royal Society of Medicine. 1979 Dec; 72(12):889-93.

17. Ceydeli A, Rucinski J, Wise L. Finding the best abdominal closure-an evidence-based overview of the literature. In Recurrent Hernia 2007 (pp. 117-122). Springer, Berlin, Heidelberg.
18. Agrawal, C.S., Tiwari, P., Mishra, S., Rao, A., Hadke, N.S., Adhikari, S. and Srivastava, A., 2014. Interrupted abdominal closure prevents burst: Randomized controlled trial comparing interrupted-x and conventional continuous closures in surgical and gynecological patients. Indian Journal of Surgery, 76(4), pp.270-276.

19. Gupta H, Srivastava A, Menon GR, Agrawal CS, Chumber $S$, Kumar $S$. Comparison of interrupted versus continuous closure in abdominal wound repair: A meta-analysis of $\mathbf{2 3}$ trials. Asian journal of surgery. 2008 Jul 1; 31(3):104-14.

\begin{tabular}{|c|c|c|c|}
\hline \multicolumn{4}{|c|}{ AUTHORSHIP AND CONTRIBUTION DECLARATION } \\
\hline Sr. \# & Author(s) Full Name & Contribution to the paper & Author(s) Signature \\
\hline 1 & Kaleem Ullah & $\begin{array}{l}\text { Study conception and design } \\
\text { and Acquisition of data. }\end{array}$ & 0 \\
\hline 2 & Shams Uddin & $\begin{array}{l}\text { Analysis and Interpretation of } \\
\text { data. }\end{array}$ & Snew \\
\hline 3 & Azam Shoib & $\begin{array}{l}\text { Drafting of manuscript and } \\
\text { review of Discussion. }\end{array}$ & 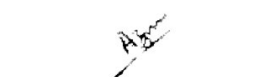 \\
\hline 4 & M. Danish Yaseen & $\begin{array}{l}\text { Statistical expertise and Result } \\
\text { compilation. }\end{array}$ & Qsest \\
\hline
\end{tabular}

